\title{
Biopsy of Anus
}

National Cancer Institute

\section{Source}

National Cancer Institute. Biopsy of Anus. NCI Thesaurus. Code C51586.

Removal of tissue from the anus for microscopic examination. 